\title{
PERSPEKTIF FILSAFAT OLAHRAGA DALAM MEWUJUDKAN MASYARAKAT SEHAT
}

Oleh: Sumaryanto

Dosen Jurusan Pendidikan Kesehatan dan Rekreasi FIK UNY

\begin{abstract}
Abstrak
Olahraga sebagai sistem pengetahuan memiliki pohon keilmuan (body of knowledge) yang secara kefilsafatan menunjukkan karakter yang unik dan komprehensif. Dalam hal ini, Filsafat merupakan seni berfikir. Jadi dapat dikatakan bahwa filsafat olahraga merupakan perenungan akan keterlibatan manusia dalam aktivitas olahraga.

Filsafat olahraga memiliki tanggung jawab penting dalam mempersatukan berbagai kajian ilmu untuk dirumuskan secara terpadu dan mengakar menuju ilmu olahraga dalam 3 dimensi ilmiahnya (Ontologi, Epistemologi, dan Aksiologi). Asumsi dasar ontologi olahraga yaitu "gerak insani" (human movement) sebagai potensi untuk dikembangkan menuju arah kesempurnaan. Gerak insani menjadi prinsip pertama dalam ontologi olahraga. Fokus olahraga pada "gerak insani", menjadikan epistemologi olahraga lebih bertendensi ke empirisme terbuka, artinya sistem yang memiliki implikasi epistemik selalu terus menerus berubah karena pengaruh eksternal; sehingga terbuka untuk pendekatan inter, antar, dan lintas disiplin. Demikian juga pada aspek aksiologi, karena sifat keterbukaan atas pengaruh aspek kehidupan yang lain, maka dalam aktivitas olahraga akan muncul nilai-nilai olahraga yang variatif. Nilai-nilai itu pada akhirnya akan kembali dan dinikmati oleh masyarakat pelaku olahraga.

Nilai-nilai yang terungkap dalam olahraga, selanjutnya akan menggambarkan fungsi olahraga dalam masyarakat. Masyarakat sehat merupakan suatu bentuk fenomena kehidupan dari insan manusia yang memiliki derajat kesehatan yang baik, mencakup kesehatan jasmani dan rohani. Pada konteks kehidupan masyarakat, eksistensi olahraga dalam perspektif filosofis memberikan kontribusi pada upaya mewujudkan masyarakat yang sehat.
\end{abstract}

Kata kunci: filsafat olahraga, masyarakat sehat.

Olahraga merupakan kegiatan yang sistematis untuk mendorong, membina serta mengembangkan potensi jasmani, rohani, dan sosial (Kemenegpora RI, 2010: 3). Olahraga dapat meningkatkan kesempatan yang ideal untuk menyalurkan energi positif dalam lingkungan persaudaraan dan persahabatan untuk menciptakan persatuan yang sehat, suasana yang akrab dan gembira, menuju kehidupan serasi, selaras, dan seimbang untuk mencapai kebahagiaan hidup yang sejati (Kosasih, 1983: 1).

Selama ini kegiatan olahraga hanya dinilai sebagai aktivitas jasmaniah tanpa didasari pemikiran bahwa dalam aktivitas olah tubuh tersebut juga terdapat nilai-nilai luhur yang tersembunyi. Hal ini kemudian memunculkan kesempatan untuk memenuhi kebutuhan dalam sistem sosial yang dapat ditunjang dari olahraga yang berhubungan dengan kehidupan bermasyarakat. Perlu diketahui bahwa olahraga dapat digunakan untuk menentukan batas 


\section{MEDIKORA Vol. IX, No 1 Oktober 2012}

kemampuan fisik / kesehatan manusia. Kehidupan masyarakat dipandang sebagai sebuah konsensus nilai secara internal, jika olahraga hadir di tengah masyarakat. Keberadaan olahraga dapat menjamin kebutuhan individu sebagai bagian dari masyarakat untuk kemudian dapat mengoreksi terjadinya kesalahan atau konflik yang ada. Dalam masyarakat Jawa, aspek raga berkaitan dengan aspek jiwa. Hal ini dipaparkan dalam Serat Wedhatama karya Mangkunegoro IV yang menjelaskan adanya empat tingkatan sembah, yaitu sembah raga, sembah cipta, sembah jiwa, dan sembah rasa (Jatmiko, 2007: 38).

Doty (2006: 1) menyatakan bahwa olahraga merupakan kebutuhan hidup manusia, karena apabila seseorang melakukan olahraga dengan teratur akan membawa pengaruh yang baik terhadap perkembangan dan kesehatan jasmaninya. Olahraga selain berguna bagi pertumbuhan perkembangan jasmani juga berpengaruh kepada perkembangan rohani pelakunya. Olahraga dapat memberikan efisiensi kerja terhadap alat-alat tubuh, sehingga peredaran darah, pernafasan, dan pencernaan menjadi teratur. Selain itu, olahraga juga merupakan bagian utama dari kegiatan masyarakat dan budaya di seluruh dunia.

Tulisan ini akan mencoba menguraikan dan mengkaji Perspektif Filsafat Olahraga berikut keterkaitannya dalam upaya mewujudkan masyarakat yang sehat.

\section{EKSISTENSI FILSAFAT OLAHRAGA}

Filsafat bisa dipahami dari berbagai sudut pandang. Filsafat dapat dipandang sebagai pandangan hidup, metode berpikir, atau sebagai sebuah ilmu. Terkait dengan kedudukan Filsafat sebagai ilmu, Filsafat adalah ilmu yang dinilai "istimewa". Keistimewaannya adalah pertama, karena dilihat dari umurnya, Filsafat adalah ilmu yang paling tua sehingga disebut sebagai induk dari segala macam ilmu khusus; dan kedua, karena sebagai ilmu, Filsafat mempunyai ruang lingkup pembahasan atau kajian yang sangat luas. Objek materialnya, atau lapangan penyelidikannya, mencakup "segala sesuatu yang ada" dan "yang mungkin ada". Dilihat dari objek materialnya ini, terlihat bahwa Filsafat juga menangani objek material yang dipelajari oleh ilmu-ilmu khusus. Antropologi, Biologi, dan Sosiologi misalnya, ketiganya membahas objek material yang sama yakni manusia. Filsafat pun juga demikian. Contoh lain, Fisika membahas tentang alam, dan begitu pula halnya dengan Filsafat. Dicakupnya berbagai macam objek material ilmu khusus oleh Filsafat ini menjadi salah satu bukti bahwa Filsafat memang memiliki ruang lingkup kajian atau lapangan penyelidikan yang sangat luas.

Kattsoff (1989: 95) menyatakan bahwa persoalan-persoalan Filsafat di samping mempunyai ciri-ciri tertentu sehingga berbeda dengan persoalan ilmiah, juga dapat digolongkan menurut jenis-jenisnya. Keluasan ruang lingkup kajian Filsafat dapat dibagi atau 


\section{MEDIKORA Vol. IX, No 1 Oktober 2012}

disistematisasi menjadi tiga cabang utama, yaitu metafisika, epistemologi, dan aksiologi. Metafisika adalah cabang Filsafat yang berusaha menangkap kenyataan terdalam dari segala sesuatu yang ada; epistemologi adalah cabang Filsafat yang berusaha menelaah sumber, watak, dan kebenaran pengetahuan dan aksiologi adalah cabang Filsafat yang berusaha menelaah tentang hakikat nilai.

Filsafat, dalam hal ini dianggap memiliki tanggung jawab penting dalam mempersatukan berbagai kajian ilmu untuk dirumuskan secara terpadu dan mengakar menuju ilmu olahraga dalam 3 dimensi ilmiahnya (ontologi, epistemologi, aksiologi) yang kokoh dan sejajar dengan ilmu lain. Ontologi membahas tentang apa yang ingin diketahui atau dengan kata lain merupakan pengkajian mengenai teori tentang ada. Dasar ontologi dari ilmu berhubungan dengan materi yang menjadi objek penelaahan ilmu, ciri-ciri essensial objek itu yang berlaku umum. Ontologi berperan dalam perbincangan mengenai pengembangan ilmu, asumsi dasar ilmu dan konsekuensinya pada penerapan ilmu. Ontologi merupakan sarana ilmiah untuk menemukan penanganan jalan masalah secara ilmiah. Dalam hal ini, ontologi berperan dalam proses konsistensi ekstensif dan intensif dalam pengembangan ilmu (Pramono, 2005: 138).

Epistemologi membahas secara mendalam segenap proses yang terlibat dalam usaha untuk memperoleh pengetahuan. Ini berkaitan dengan metode keilmuan dan sistematika isi ilmu. Metode keilmuan merupakan suatu prosedur yang mencakup berbagai tindakan pikiran, pola kerja, cara teknis, dan tata langkah untuk memperoleh pengetahuan baru atau mengembangkan yang telah ada. Sistematisasi isi ilmu dalam hal ini berkaitan dengan batang tubuh ilmu, dimana peta dasar dan pengembangan ilmu pokok dan ilmu cabang dibahas disini.

Aksiologi, ilmu membahas tentang manfaat yang diperoleh manusia dari pengetahuan yang didapatnya. Bila persoalan value free and value bound ilmu mendominasi fokus perhatian aksiologi pada umumnya, maka dalam hal pengembangan ilmu baru seperti olahraga ini, dimensi aksiologi diperluas lagi sehingga secara inheren mencakup dimensi nilai kehidupan manusia seperti etika, estetika, religius (sisi dalam aksiologis), dan juga interrelasi ilmu dengan aspek-aspek kehidupan manusia dengan sosialitasnya (sisi luar aksiologis). Keduanya merupakan aspek transfer dari permasalahan transfer pengetahuan.

Istilah olahraga mencakup pengertian yang luas, bukan hanya olahraga kompetitif, tetapi juga aktivitas pada waktu senggang sebagai pelepas lelah dan kegiatan pembinaan jasmani. Meskipun amat beragam mengenai bentuk dan jenis olahraga, namun masih dapat diidentifikasi persamaan umum yang menunjukkan ciri yang khas yang disebut "inner 


\section{MEDIKORA Vol. IX, No 1 Oktober 2012}

horizon" suatu objek, esensi dan inti yang paling dalam dari olahraga dibentuk oleh sebuah kriteria yakni makna bermain dan permainan. Kriteria yang paling otentik adalah bahwa kegiatan tersebut didasarkan pada faktor kebebasan dan kesengajaan atas dasar kesadaran pelakunya untuk berbuat; inilah yang membedakan ciri bermain yang sejati. Tindakan sejati dalam olahraga tidak dipandang sebagai sesuatu yang tidak menyenangkan tetapi merupakan sumber dari keceriaan (joy) dan kebahagiaan (happiness) (Lutan dan Sumardianto, 2000: 9).

Olahraga merupakan ilmu, secara internasional, mulai muncul pertengahan abad 20 dan di Indonesia secara resmi dibakukan melalui deklarasi ilmu olahraga tahun 1998. Beberapa akademisi dan masyarakat awam memang masih pesimis terhadap eksistensi ilmu olahraga, khususnya di Indonesia, terutama dengan melihat kajian dan wacana akademis yang masih sangat terbatas dan kurang integral. Namun sebagai suatu ilmu baru yang diakui secara luas, ilmu olahraga berkembang seiring kompleksitas permasalahan yang ada dengan ketertarikan-ketertarikan ilmiah yang mulai bergairah menunjukkan eksistensi ilmu baru ini ke arah kemapanan.

Juynboll (1923: 98) menyampaikan bahwa secara etimologis kata olahraga berasal dari bahasa Jawa Kuno yang tersusun dari dua kata, yaitu olah dan raga. Kata olah berarti perbuatan atau kegiatan, sedangkan raga berarti anyaman, rangka, atau wadah. Sampai sekarang istilah olahraga masuk sebagai kata benda, namun kemudian olahraga juga dianalogikan dengan istilah sport. Berkaitan dengan istilah sport, Rijsdorp (1971: 44) mengatakan bahwa sport mempunyai watak permainan, akan tetapi sport tidak sama dengan permainan. Permainan mempunyai makna yang lebih luas dari pada sport. Sport dapat dipandang sebagai bentuk permainan yang mempunyai jenis tersendiri. Sejalan dengan

Rijsdrop, Lutan dan Sumardianto (2000: 1) berpendapat bahwa konsep dasar dalam bidang keolahragaan meliputi bermain (play), pendidikan jasmani (physical education), olahraga (sport), rekreasi (recreation), tari (dance), dan gerak insani yang menjadi inti dari kegiatan dalam bidang olahraga.

Dunia olahraga penuh dengan makna filosofis. Nilai-nilai positif dalam olahraga merupakan micro-cosmos yang menentukan pokok-pokok dan mencerminkan nilai-nilai sosial (Eldon dan Spalitzer, 1983: 45). Dalam filsafat ilmu tidak dapat dipungkiri bahwa berfilsafat merupakan manifestasi kegiatan intelektual yang telah meletakkan dasar-dasar paradigmatik bagi tradisi dalam kehidupan masyarakat ilmiah (Wibisono, 2001: 3). Nilainilai yang terungkap dalam olahraga, selanjutnya akan menggambarkan fungsi olahraga dalam masyarakat. 


\section{MEDIKORA Vol. IX, No 1 Oktober 2012}

Penjelasan tentang konsep olahraga hingga tuntas tidak akan berhasil diperoleh karena definisi olahraga mengalami perubahan, seiring dengan perubahan sosial dan pengaruh iptek. Pada tingkat internasional pun, para ahli dihadapkan pada masalah dalam perumusan definisi olehraga sehingga dijumpai definisi yang cukup beragam sesuai dengan sudut pandang disiplin ilmu keolahragaan yang ditekuni (Lutan dan Sumardianto, 2000: 4-5). Adapun inti kajian Ilmu Keolahragaan adalah Teori Latihan, Belajar Gerak, Ilmu Gerak, Teori Bermain dan Teori Instruksi yang didukung oleh ilmu-ilmu Kedokteran Olahraga, Ergofisiologi, Biomekanika, Sosiologi Olahraga, Pedagogi Olahraga, Psikologi Olahraga, Sejarah Olahraga, dan Filsafat Olahraga.

\section{MASYARAKAT SEHAT}

Dalam undang-undang nomor 9 tahun 1960 Bab 1 Pasal 2 tentang pokok-pokok kesehatan, menyatakan bahwa sehat adalah keadaan sehat yang meliputi sehat badan, rohani (mental), dan sosial, serta bukan hanya keadaan yang bebas dari penyakit, cacat, dan kelemahan. Mengacu pada pendapat di atas, pengertian sehat mengandung tiga aspek, yaitu fisik, mental, dan sosial. Olahraga memberikan manfaat yang cukup besar dalam pencapaian manusia yang sehat dan mencakup ketiga aspek tersebut.

Pemerintah bersama-sama dengan masyarakat memiliki tanggungjawab moral untuk memberdayakan masyarakat agar memiliki pengetahuan memadai tentang kesehatan, memiliki kesadaran (awareness), dan pada akhirnya akan berpartisipasi aktif dalam pembangunan kesehatan secara menyeluruh. Pemberdayaan tersebut terutama ditujukan untuk meningkatkan kemampuan mereka dalam memahami, memelihara, meningkatkan, dan melindungi kesehatan secara mandiri. Dari sisi kebijakan mungkin telah memadai, namun pekerjaan rumah terbesar adalah bagaimana mewujudkan kebijakan tersebut agar berdampak positif terhadap pemberdayaan masyarakat di lapangan (Hari Nusantara, 2011:2).

Upaya menciptakan partisipasi masyarakat untuk memelihara dan meningkatkan kesehatan secara mandiri sejauh ini sudah banyak dilakukan baik oleh pemerintah, swasta maupun lembaga non-pemerintah, akan tetapi partisipasi masyarakat masih belum menggembirakan. Oleh karena itu, seiring demokratisasi dan pelaksanaan otonomi daerah, pembangunan bidang kesehatan harus mengarusutamakan program-program yang lebih diarahkan kepada pemberdayaan dan proses memandirikan masyarakat, termasuk kebutuhan untuk hidup sehat. Ke depan, pembangunan bidang kesehatan perlu lebih ditekankan pada upaya menumbuh-kembangkan dorongan belajar dalam masyarakat agar mereka menyadari pentingnya pola hidup sehat. Proses penyadaran ini hendaklah diposisikan sebagai kegiatan 


\section{MEDIKORA Vol. IX, No 1 Oktober 2012}

yang bersifat bottom-up, di mana masyarakat diposisikan selaku subjek dan pelaku pembangunan kesehatan. Dengan demikian, proses pemberdayaan bisa tercipta melalui dorongan internal masyarakat sendiri, bukan sesuatu yang dipaksakan dari atas. Karenanya, pemerintah lebih memposisikan diri sebagai motivator dan fasilitator.

Secara teoritis, partisipasi akan tercipta jika masyarakat telah berdaya. Agar masyarakat berdaya, sarana kesehatan mutlak dibutuhkan. Di sinilah pemerintah memainkan peran penting sebagai penyedia sarana-prasarana kesehatan beserta infrastruktur pendukungnya. Namun pemberdayaan masyarakat tidak boleh berhenti pada penyediaan sarana-prasarana belaka, tetapi program bersifat edukatif secara berkelanjutan harus dilakukan. Dengan model pemberdayaan tersebut, masyarakat akan memiliki kesiapan mengolah sumberdaya, kesempatan, pengetahuan dan keterampilan yang mereka miliki untuk meningkatkan kapasitas mereka dan berpartisipasi dalam kebijakan atau program kesehatan yang sangat berpengaruh terhadap kualitas kehidupan mereka.

Konsep tentang tanggung jawab terhadap kesehatan diri sendiri terus berkembang sampai pada masa kehidupan masyarakat dewasa ini. Semangat individualisme dan humanisme yang berkembang sebagai akibat dari munculnya kesadaran manusia juga ikut memperkuat rasa tanggung jawab setiap manusia terhadap kesehatan dirinya. Setiap orang, baik yang mengambil keputusan sendiri maupun yang berkonsultasi dengan tenaga kesehatan, memiliki kewajiban moral untuk mengusahakan dan memelihara kesehatannya.

Kajian-kajian tentang kesehatan dan kebugaran, selain dilakukan dalam pendidikan formal, juga dikembangkan melalui karya-karya ilmiah dan penelitian yang dilakukan oleh para pemikir Kesehatan Olahraga. Pengakuan terhadap arti pentingnya Olahraga bagi kesehatan memang sudah berkembang meluas. Olahraga, dengan kata lain, sudah dipahami sebagai salah satu komponen penting yang menunjang keberhasilan manusia di dalam mempertahankan kesehatan dan kebugarannya.

Olahraga bukanlah hal yang baru bagi manusia di era kontemporer seperti sekarang ini. Aktivitas fisik yang bertujuan untuk menjaga kebugaran dan kesehatan sudah dapat dilihat dalam kehidupan sehari-hari. Berbagai sarana olahragapun diciptakan untuk mendukung gaya hidup tersebut, mulai dari munculnya pusat-pusat kebugaran (fitness centers) hingga inovasi teknologi baru yang ditawarkan melalui iklan-iklan di media elektronik. Hal tersebut menjadi salah satu bukti bahwa olahraga bukan hanya satu hal yang penting, namun juga merupakan bagian yang tidak terpisahkan dari gaya hidup manusia saat ini.

Saat ini, munculnya pusat-pusat kebugaran dan berbagai macam sarana olahraga lainnya, memang bukanlah hal yang mengejutkan. Tempat-tempat tersebut muncul sebagai 


\section{MEDIKORA Vol. IX, No 1 Oktober 2012}

salah satu indikasi atau gambaran bahwa manusia peduli dan menganggap bahwa kesehatan merupakan bagian penting di dalam hidup. Kesehatan adalah hal berharga yang penting untuk dipertahankan, terlebih ketika berbagai macam penyakit selalu mengancam kelangsungan hidup manusia. Mengingat pentingnya latihan fisik (physical exercise) seperti ini, tidak cukup kiranya apabila olahraga hanya dijadikan sebagai gaya hidup. Olahraga perlu dikembangkan dan dikaji dalam kerangka keilmuan, yaitu dalam bentuk Ilmu Keolahragaan.

Organisasi Kesehatan Sedunia atau WHO mendefinisikan sehat adalah "suatu keadaan sehat yang baik, baik fisik, mental maupun sosial. Tujuan dari WHO ialah tercapainya tingkat kesehatan yang paling tinggi oleh semua orang. Kebugaran fisik didefinisikan sebagai "kemampuan untuk melakukan pekerjaan sehari-hari dengan bertenaga dan penuh kesiagaan, tanpa kelelahan yang tidak semestinya dan dengan cukup energi, sehingga tetap dapat menikmati waktu luang dan menanggulangi keadaan-keadaan mendadak yang tidak diperkirakan”. Konsep kebugaran fisik sekarang dibedakan antara kebugaran yang berkaitan dengan kesehatan dan yang berkaitan dengan performance. Kebugaran yang berkaitan dengan kesehatan memerlukan suatu tingkat yang cukup dari empat komponen kebugaran dasar yaitu daya tahan jantung-paru-peredaran darah, lemak tubuh, kekuatan dan daya tahan otot, dan kelenturan sendi. Kebugaran yang berkaitan dengan performance memerlukan suatu tingkat kebugaran yang berkaitan dengan kesehatan yang cukup tinggi, disamping tingkat yang cukup dari tambahan empat komponen kebugaran dasar, yaitu ketahanan otot, tenaga otot, ketangkasan, dan kecepatan. Kebanyakan orang yang melakukan olahraga secara teratur sependapat bahwa salah satu dari alasan utama mengapa mereka melakukan itu ialah karena hal itu menyebabkan mereka merasa lebih enak. Kenyataan bahwa olahraga menyebabkan mereka mencapai dan mempertahankan keadaan sehat dan kebugaran fisik tidak begitu dihiraukan. Tetapi bila seseorang melalui olahraga dapat mencapai keadaan sehat dan kebugaran yang baik, barulah ia dapat menghargai keadaan tersebut (Giam, 1992: 8-10).

\section{RELEVANSI FILSAFAT OLAHRAGA DALAM MEWUJUDKAN MASYARAKAT SEHAT}

Filsafat sebenarnya bukanlah hal yang asing bagi manusia. Cara manusia menghadapi tantangan di dalam kehidupannya, baik dalam hubungannya dengan diri sendiri, alam, maupun orang lain, selalu saja disertai dengan filosofi tertentu, meskipun kebanyakan dari manusia menyangkal atau tidak menyadari hal ini. Cara manusia menjaga kedisiplinan diri dan membangun etos kerja, itu sangat dipengaruhi oleh filsafat. Cara manusia menjalin 


\section{MEDIKORA Vol. IX, No 1 Oktober 2012}

keharmonisan hidup dengan sesama manusia, itu juga sangat dipengaruhi oleh filsafat hidupnya. Terlebih lagi cara manusia memperlakukan alam, itu sangat kaya dengan pandangan manusia tentang alam itu sendiri, yang tidak lain juga merupakan pandangan filsafat tertentu. Singkatnya, filsafat memang terkesan asing, namun sebenarnya filsafat sangat dekat dengan manusia. Titus dan Smith, dalam Living Issues in Philosophy (1986: 5), mengemukakan bahwa persoalan filsafat adalah persoalan kehidupan. Mendalami filsafat menjadi sangat penting karena menghadapi persoalan semacam itu merupakan bagian yang sangat penting dari usaha untuk mengatasi persoalan di dalam hidup.

Pada hakikatnya Filsafat Olahraga merupakan fenomena khas dalam kehidupan manusia dan berdimensi luas. Sebagai sistem pengetahuan, Olahraga memiliki pohon keilmuan (body of knowledge). Bangunan keilmuan olahraga secara kefilsafatan menunjukkan karakter yang unik dan komprenhensif. Hal tersebut tercermin dalam landasan ontologi, epistemologi, dan aksiologi olahraga. Asumsi dasar ontologi olahraga adalah "gerak insani" (human movement) sebagai potensi untuk dikembangkan menuju arah kesempurnaan. Gerak insani menjadi prinsip pertama dalam ontologi olahraga. Fokus olahraga pada "gerak insani" menjadikan epistemologi olahraga lebih bertendensi ke empirisme terbuka. Artinya sistem yang memiliki implikasi epistemik selalu terus menerus berubah karena pengaruh eksternal; sehingga terbuka untuk pendekatan inter, antar, dan lintas disiplin. Perubahan itu juga terjadi pada aspek aksiologinya. Sifat keterbukaan atas pengaruh aspek kehidupan yang lain itu, akan melahirkan nilai-nilai olahraga yang variatif.

Secara sederhana, Olahraga dapat dijadikan alat untuk meningkatkan kebugaran tubuh seseorang, tidak hanya secara jasmani tetapi juga secara rohani. Apabila dikaji menurut Filsafat Olahraga (Pramono, 2005:138), hal ini lebih ditekankan pada masalah sikap, perilaku, nilai, moral, dan atau fairplay manusia dengan permasalahannya yang sering muncul di dalam praktik berolahraga. Dengan demikian, Filsafat Olahraga menerangkan bagaimana sikap, perilaku, nilai, moral, dan atau fairplay dalam kegiatan olahraga. Pemahaman terhadap nilai-nilai olahraga penting di praktikan dalam dunia olahraga, karena banyak praktik berolahraga yang menyimpang dari nilai-nilai luhur olahraga, seperti perkelahian antar suporter sepak bola, bahkan antar pemain masing-masing tim. Ini bukti bahwa sikap, perilaku, nilai, moral, dan fairplay yang terdapat pada filsafat olahraga belum tertanam dalam setiap tim atau bahkan individu masing-masing.

Dengan memahami Filsafat Olahraga, maka akan dipahami juga nilai-nilai yang terkandung dalam aktivitas olahraga tersebut. Oleh karena itu ketika masyarakat beraktivitas 


\section{MEDIKORA Vol. IX, No 1 Oktober 2012}

olahraga diharapkan sekaligus masyarakat tersebut akan mendapatkan nilai-nilai olahraga yang terkandung didalamnya. Satu diantara nilai-nilai yang ada adalah diperolehnya kesehatan bagi masyarakat yang melakukan aktivitas olahraga.

Menurut Kuntaraf dan Kuntaraf (1992:12-14), ada banyak keuntungan berolahraga yang perlu diketahui, diantaranya adalah sebagai berikut.

1. Membuat jantung lebih berdaya guna. Otot jantung diperkuat dan jumlah darah yang dipompakan lebih banyak.

2. Menormalisasi tekanan darah. Bila tekanan darah tinggi, olahraga akan menurunkannya. Namun bila tekanan darah rendah, olahraga justru akan menaikkannya menjadi normal.

3. Memperbesar kapasitas darah dalam membawa oksigen sehingga lebih banyak darah yang dapat mencapai keseluruh bagian tubuh manusia.

4. Menurunkan denyut nadi dalam keadaan istirahat. Ini sangatlah penting sebab dengan berkurangnya denyutan nadi, jantung tidak perlu bekerja terlalu keras.

5. Memperlancar peredaran darah. Aliran darah adalah sungai kehidupan, sebab darah membawa oksigen, zat makanan, dan zat-zat penting lainnya ke seluruh tubuh manusia. Darah juga yang membawa produk sisa metabolisme ke ginjal, paru-paru, dan kulit untuk dikeluarkan dari tubuh.

6. Merangsang pernapasan yang dalam yang menyebabkan paru-paru berkembang melalui refleks dan reaksi kimia. Hal ini menyebabkan paru-paru lebih berdayaguna, sebab lebih banyak oksigen akan disalurkan ke dalam darah dan lebih banyak karbon dioksida yang dapat dibuang dari dalam tubuh.

7. Membuat otot yang tegang menjadi luwes, serta meredakan emosi yang negatif. Ini akan membuat anda merasa lebih senang terhadap diri sendiri, sebab kemarahan dan frustasi dapat dikurangi.

8. Menambah tenaga listrik pada otak dan sel saraf. Hal ini akan memberikan keseimbangan yang lebih baik antara susunan saraf sadar dan tidak sadar.

9. Menolong pencernaan dan mendorong kegiatan usus, mengurangi gas dan sembelit.

10. Menguatkan otot, tulang, dan jaringan pengikat tubuh. Ini akan menghindarkan seseorang dari kehilangan mineral tulang, dengan demikian ia akan terhindar dari penyakit osteoporosis.

11. Memberikan keseimbangan fisiologis kepada sistem endokrin seseorang sehingga kelenjar pituitari, pankreas, adrenalin, dan seks akan menjadi lebih berdayaguna.

12. Olahraga mempertajam kekuatan mental dan menambah kapasitas seseorang dalam berfikir. 


\section{MEDIKORA Vol. IX, No 1 Oktober 2012}

13. Memperindah tubuh dan wajah.

14. Menolong mengurangi kelebihan lemak, bukan hanya dengan pembakaran kalori, bahkan dengan mengatur kadar metabolisme hingga ia akan mengurangi berat badan walaupun dalam keadaan tidur.

15. Olahraga menambah tenaga, sebab olahraga menghasilkan lebih banyak tenaga daripada daripada tenaga yang dipakainya.

16. Mengurangi proses menua. Olahraga menyebabkan seseorang awet muda.

17. Menambah daya tahan dan dan memperlambat keletihan. Bahkan olahraga adalah resep khusus untuk keletihan emosi.

18. Merangsang produksi endorphin dari otak. Endorphin adalah hormon yang dihasilkan dari kelenjar pituitari yang dapat memberikan perasaan tenang dan daya tahan kepada perasaan nyeri.

19. Menolong seseorang untuk mengatasi ketegangan kehidupan.

20. Mengurangi risiko untuk mendapatkan kanker dan penyakit jantung.

21. Menolong seseorang untuk dapat tidur lebih nyenyak di malam hari.

22. Bila dikombinasikan dengan makanan yang baik, olahraga akan menolong seseorang mengurangi risiko arteriosclerosis, tekanan darah tinggi, diabetes, osteoporosis, obesitas, kanker, dan penyakit keturunan kronis lainnya.

23. Memberikan keseimbangan berat badan.

24. Menolong seseorang untuk mengurangi kolesterol, LDL, dan trigliserides, dan menaikkan HDL bila terlalu rendah.

25. Menolong otak untuk berfungsi dengan lebih baik dalam berfikir.

26. Berolahraga dibawah sinar matahari menyebabkan lebih banyak vitamin D yang dihasilkan serta lebih banyak penyerapan kalsium dan zat besi.

27. Mengurangi ketegangan dan depresi.

28. Bagi kelompok yang dilahirkan dengan pembuluh darah sempit, olahraga dapat memperlambat kemungkinan serangan penyakit jantung.

\section{KESIMPULAN}

Olahraga dapat didefinisikan sebagai sebuah aktivitas seseorang yang terinstitusionalisasi dan melibatkan kemampuan fisik. Selanjutnya, penggunaan keterampilan fisik yang kompleks oleh individu peserta aktivitas tersebut, termotivasi oleh kombinasi antara kepuasan diri dan motivasi eksternal berupa penghargaan dari partisipasinya. Dukungan dalam olahraga sering kali diiringi dengan identifikasi ekstrem dari para pelaku 


\section{MEDIKORA Vol. IX, No 1 Oktober 2012}

olahraga dan nilai-nilai yang diterima sebagai dasar kesuksesan para pelaku olahraga. Identifikasi ini membawa olahraga ke dalam hidup para pelakunya dan mencetak sebuah perhatian terhadap orientasi jangka panjang. Filsafat olahraga lebih ditekankan kepada masalah sikap, perilaku, nilai, moral, dan atau fairplay manusia dengan permasalahannya yang sering muncul di dalam praktik-praktik kegiatan olahraga. Secara sederhana Olahraga adalah aktivitas untuk melatih tubuh seseorang, tidak hanya secara jasmani tetapi juga secara rohani. Tumbuhnya kesadaran tentang rasa tanggung jawab terhadap kesehatan diri sendiri memberikan kemajuan yang besar terhadap kajian tentang kesehatan dan olahraga. Informasi dan temuan-temuan baru tentang diet, olahraga, dan saran-saran lain yang membantu individu untuk tetap sehat pun menjadi sangat dibutuhkan. Seiring dengan meningkatnya kebutuhan ini, satu per satu pemikir di dunia kesehatan dan keolahragaanpun mengemukakan gagasan mereka untuk membantu masyarakat dalam mengupayakan dan memelihara kesehatan mereka masing-masing.

\section{DAFTAR PUSTAKA}

Doty, Joseph. (2006). "Sports Build Character", Journal of College \& Character. Volume VII, No. 3, April 2006.

Eldon, Snyder and Etmer Spalitzer. (1983). Social Aspects of Sport. New Jersey: Prentice Hall, Inc.

Fromm, Erich. (1995). The Sane Society penterjemah Murtianto, Thomas Bambang. Jakarta: Yayasan Obor Indonesia.

Giam, C K. (1992). Sport, Medicine, Exercise and Fitness penterjemah Hartono Satmoko. Jakarta: Binarupa Aksara.

Hari Nusantara. (2011). Masyarakat Berdaya Masyarakat Sehat. Jakarta: Direktorat Pengelolaan Media Publik.

Jatmiko, Adityo. (2007). Tafsir Serat Wedhatama. Yogyakarta: Pura Pustaka.

Juynboll, H.H. (1923). Oud Javaansch-Nederlandsche Woordenlijs. W. Versluys, NV. Amsterdam.

Kathleen Liwijaya Kuntaraf dan Jonathan Kuntaraf. (1992). Olahraga Sumber Kesehatan. Jakarta: Advent Indonesia.

Kattsoff, Louis. (1989). Elements of Philosophy penterjemah Soejono Soemargono. Yogyakarta: Tiara Wacana. 


\section{MEDIKORA Vol. IX, No 1 Oktober 2012}

Kemenpora RI. (2010). Undang-undang RI Nomor 3 tahun 2005 tentang Sistem Keolahragaan Nasional. Jakarta: Biro Humas dan Hukum Kemenpora RI.

Kosasih, Engkos. (1983). Olahraga Teknik \& Program Latihan. Jakarta: Akademika Pressindo.

Lutan, Rusli dan Sumardianto. (2000). Filsafat Olahraga. Jakarta: Depdiknas.

Pramono, Made. (2005). Dasar-Dasar Filosofis Ilmu Olahraga. Yogyakarta: Badan Penerbitan Fakultas Filsafat UGM.

Rijsdorp, K. (1971). Gymnologie, Het Spectrum NV, Utrecht.

Sumosardjuno, Sadoso. (1992). Pengetahuan Praktis Kesehatan dalam Olahraga. Jakarta: Gramedia.

Titus, Harold and Nolan Smith. (1986). Living Issues on Philosophy penterjemah H.M. Rasjidi. Jakarta: Bulan Bintang.

Wibisono, Koento. (2001). Bahan Kuliah Filsafat Ilmu, Hubungan Filsafat Ilmu, Ilmu Pengetahuan dan Budaya. Surabaya: Pasca Sarjana UNAIR. 